
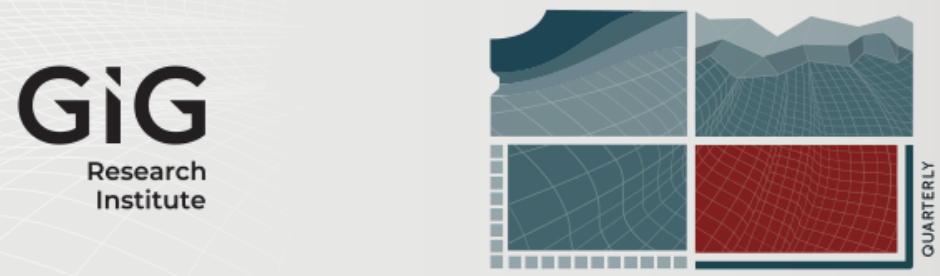

JOURNAL

OF

SUSTAINABLE

MINING

\title{
A systematic review of the use of environmental economics in the mining industry
}

Author(s) ORCID Identifier:

Maria Menegaki iD 0000-0001-8844-3014

Dimitris Damigos (D) 0000-0003-0142-7156

Follow this and additional works at: https://jsm.gig.eu/journal-of-sustainable-mining

Part of the Economics Commons, Environmental Indicators and Impact Assessment Commons, Mining Engineering Commons, Natural Resource Economics Commons, and the Sustainability Commons

\section{Recommended Citation}

Menegaki, Maria and Damigos, Dimitris (2020) "A systematic review of the use of environmental economics in the mining industry," Journal of Sustainable Mining: Vol. 19 : Iss. 4 , Article 5.

Available at: https://doi.org/10.46873/2300-3960.1034

This Review is brought to you for free and open access by Journal of Sustainable Mining. It has been accepted for inclusion in Journal of Sustainable Mining by an authorized editor of Journal of Sustainable Mining. 


\title{
A systematic review of the use of environmental economics in the mining industry
}

\author{
Abstract \\ Environmental economics is increasingly being used in project appraisals, environmental liability \\ estimates and design of market-based instruments. Mining, an actor capable of causing adverse effects \\ on the environment, human health and well-being, has already been affected by these developments, at a \\ great extent. Up to date, several research studies have been carried out to monetise the externalities of \\ mining projects. Nevertheless, a systematic review of these publications has not been carried out, yet. \\ This paper aims to fill this gap in the literature by investigating (i) the main non-market valuation \\ techniques used; (ii) the main external costs or benefits of mining projects monetized; and (iii) the \\ monetary estimates of mining-related externalities. The analysis shows that practically all economic \\ valuation techniques have been implemented towards assessing, in monetary terms, the mining impacts \\ on the environment. However, the findings from the statistical analysis of the reveal a wide range of \\ monetary estimates, which are attributed not only to the valuation methods and assumptions used but \\ also to the specific characteristics of the mining projects in question. Also, the research draws directions \\ for future research, as the analysis of the published studies indicates areas of limited availability of \\ estimates or high heterogeneity between the available estimates.
}

\section{Keywords}

mining, quarrying, externalities, environmental economics, nonmarket valuation, systematic review

\section{Creative Commons License}

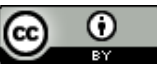

This work is licensed under a Creative Commons Attribution 4.0 License.

\section{Cover Page Footnote}

Conflicts of interest The authors declare no conflict of interest. Ethical statement The authors state that the research was conducted according to ethical standards. Funding body None. 


\title{
A systematic review of the use of environmental economics in the mining industry
}

\author{
Maria Menegaki*, Dimitris Damigos
}

National Technical University of Athens, School of Mining and Metallurgical Engineering, Greece

\begin{abstract}
Environmental economics is increasingly being used in project appraisals, environmental liability estimates and design of market-based instruments. Mining, an actor capable of causing adverse effects on the environment, human health and well-being, has already been affected by these developments, at a great extent. Up to date, several research studies have been carried out to monetise the externalities of mining projects. Nevertheless, a systematic review of these publications has not been carried out, yet. This paper aims to fill this gap in the literature by investigating (i) the main non-market valuation techniques used; (ii) the main external costs or benefits of mining projects monetised; and (iii) the monetary estimates of mining-related externalities. The analysis shows that practically all economic valuation techniques have been implemented towards assessing, in monetary terms, the mining impacts on the environment. However, the findings from the statistical analysis reveal a wide range of monetary estimates, which are attributed not only to the valuation methods and assumptions used but also to the specific characteristics of the mining projects in question. Also, the research draws directions for future work, as the analysis of the published studies indicates areas of limited availability of estimates or high heterogeneity between the available estimates.
\end{abstract}

Keywords: mining, quarrying, externalities, environmental economics, nonmarket valuation, systematic review

\section{Introduction}

$\mathrm{O}$ ver the last four decades, there is a growing interest in the monetary assessment of external costs (or benefits) of various economic operations on society using environmental economics valuation techniques. A significant boost in this direction was given by certain legislative acts relating to environmental protection and restoration. In particular, three issues played a major role in the development of environmental economics: the cost-benefit analysis of projects and policies, the natural resource damage assessment and the market-based instruments (e.g. pollution taxes and environmental subsidies) that are increasingly being used as a means of achieving specific environmental targets [1-4].

The theory of social cost-benefit analysis (CBA) was founded by the economists Nicholas Kaldor and
John Hicks in the 1930s [5] and has been developed independently of environmental valuation to appraise projects (or policies) from a societal perspective rather than a private one [6]. Yet, as Pearce argues: "... Two of the triumphs of environmental economics have been to emphasize the incompleteness of appraisals that omit environmental change and to develop the means of incorporating environmental values into appraisal ..." [1]. The first environmental valuation surveys for informing CBA studies were carried out in the U.S. in the 1950s and were expanded for evaluating new regulations in the late 1970s [3]. Nevertheless, the U.S. Flood Control Act of 1936 is often regarded as the first use of CBA [5]. In Europe, the interest in CBA arose in the 1980s as a result of growing awareness of the US applications [4]. Manuals for CBA can be found in a few European countries mainly for transportation projects but they do not always provide guidelines for economic valuation of environmental impacts [3]. CBA applications were first implemented in the UK,

Received 13 November 2020; revised 22 December 2020; accepted 29 December 2020.

Available online 31 December 2020

* Corresponding author.

E-mail address: menegaki@metal.ntua.gr (M. Menegaki). 
Germany, Scandinavian countries, and the Netherlands [7]. At the European Commission (EC) level, CBA was first introduced in 1994 by the Directorate-General for Regional Policy, with the release of the first CBA Guide [8]. Nowadays, CBA is mandatory to apply for co-funding to the European Regional Development Fund and the Cohesion Fund, following the latest version of the EC CBA Guide [9].

Natural resource damage assessment (NRDA) regulations, also known as environmental liability, were introduced in the US legislation in the 1970s with the Trans-Alaska Pipeline Authorization Act $[2,10]$. The environmental liability was extended beyond the oil industry with the Comprehensive Environmental Response, Compensation, and Liability Act (CERCLA) of 1980 and the Superfund Amendments and Reauthorization Act (SARA) of 1986 [2]. In 1990, the Oil Pollution Act (OPA) passed, after a year of the Exxon Valdez oil spill, which establishes liability for damages resulting from oil pollution. CERCLA mandates that the damages from an injury cannot exceed the value of the lost resource, which includes use values and existence or non-use values. Under OPA, the environmental liability has three components: (i) the costs of restoring, replacing or providing the equivalent of the damaged resources, (ii) the compensation for interim losses and (iii) the reasonable cost of assessing the damages [11]. In Europe, a similar approach has been established on enforcement of claims to remedy environmental damages by the Environmental Liability Directive (ELD) 2004/35/ EC. The ELD applies to damages to land, water and species and natural habitats and allows for three types of remediation, namely (i) restoration of the damaged resource to its baseline condition; (ii) complementary remediation when the affected site cannot be fully restored, and (iii) compensatory remediation of interim losses [12]. Also, the ELD notes that 'alternative valuation techniques shall be used, where restoration of services is not possible to inform the level of remediation [12].

Market-based instruments (MBIs) have emerged as an alternative to command-and-control measures. MBIs focus on market-level outcomes and, if properly designed and implemented, may protect and improve the environment at the lowest possible overall cost to society [13]. MBIs, include in general, tradable permits designed to reduce emissions or overexploitation of resources, environmental taxes that change prices, environmental charges that cover costs of environmental services and abatement measures, and environmental subsidies to foster new technologies and markets for environmental goods and services [14]. Moreover, market friction, such as voluntary exchange of scarce resource rights, liability rules and information programs, such as energy-efficiency labels, are also considered as MBIs [13]. Nowadays, there are several hundreds of different MBIs, including among others effluent charges, deposit-refund schemes, tradable permits, sales and value-added taxes, etc., intending to change the behaviour of producers and consumers (for further details readers may refer to $[13,14])$.

Mining, being an activity capable of causing adverse effects on the environment, human health and well-being (e.g. [15-18]), could not stay unaffected from these developments. Environmental economics valuation techniques have been used in several real case applications For instance, in 1983, the Colorado State filed a natural resource damage lawsuit against the owner and operator of the Eagle Mine site at that time for impacts to the Eagle River and surrounding areas. In 1985, economic analyses were conducted on behalf of the plaintiff and of the defendant to estimate the damages on the environment. There were significant discrepancies between the two studies due to different assumptions used [2]. In 1988, the Colorado State and the operator of the mine entered into a consent remedial action plan. In 1990, the Resource Assessment Commission conducted a study to assess the environmental value of the Kakadu Conservation Zone, intending to determine whether mining should be permitted in this area or whether the area should be added to Kakadu National Park instead [19]. Although the non-market valuation estimates were removed from the final report, it was argued that many Australians are highly concerned about the environmental consequences of mining and place relative high values on the wilderness [20]. In the UK, a flat rate environmental tax, i.e. the Aggregate Levy, was introduced on the exploitation of rock, sand and gravel to encourage the use of secondary and recycled aggregates [21]. The tax is equal to GBP 2 per ton of aggregates extracted, and proportionally for any amount under that weight.

The need for a value measure on the otherwise intangible environment in the mining industry for project appraisals, damage assessments and implementation of MBIs, is undeniable. This fact is also reflected in the relevant literature, where there is a growing body of studies focusing on the monetisation of mining-related externalities. This paper aims to conduct a systematic review on this topic and, to the best of the authors' knowledge this is the first such study. 
The rest of the paper is structured, as follows: Section 2 provides the methodological background of the systematic review, Section 3 presents and discusses the main findings of the review with regards to the basic research questions, and, finally, Section 4 draws the conclusions and raises suggestion for future work.

\section{Materials and methods}

There exist several publications providing guidelines on how to perform systematic reviews (e.g. [22-27]). This work follows the general steps of these guidelines, especially those focused on systematic reviews in environmental management (e.g. [26]). The systematic review presented in this paper aims to analyse the use of non-market valuation techniques in mining-related projects and activities. To this end, the main research questions addressed by the review are the following:

(i) What are the main non-market valuation techniques used to monetising the environmental and social impacts of mining projects?

(ii) What are the main external costs or benefits of mining projects monetised employing nonmarket valuation?

(iii) What is the economic evidence (i.e. valuation estimates) on the external costs or benefits of mining projects?

For the review, the definitions of the environmental economic values and techniques are adopted from the related literature of environmental economics (e.g. [2]). Specifically, the Total Economic Value (TEV) of an environmental resource or service includes all use (i.e. direct, indirect and option values) and non-use values (existence, altruistic and bequest values). The direct use values refer to the actual use of a resource or service by the individuals, for either commercial purposes or recreation. The indirect use values derive from the ecosystem functions. The option value reflects an individual's willingness to pay (WTP) for the option of using the resource or service examined in the future. The non-use values typically consist of existence values, which are related to moral reasons and reflect WTP to preserve a resource in existence without actual or planned use for anyone; altruist values, which express WTP of an individual to make the resource or service available to others in the current generation; and the bequest values that derive from an individual's WTP to ensure the use of the natural resource or service for future generations.
The above-mentioned economic values of the environment can be estimated using non-demand (referred also as conventional market approaches) or demand curve methods. The non-demand curve techniques involve the use of market prices, replacement costs, damage avoided costs, mitigation costs, dose-response methods and opportunity costs. The demand curve techniques are categorised into two different types, i.e. revealed and stated preference methods. The revealed preference methods elicit preferences from the actual behaviour of individuals, based on market information. The two mainly used approaches are the Travel Cost method which is used in measuring the value of recreational sites and the Hedonic Pricing method which uses transactions in the housing market to estimate the value of environmental goods or services that are reflected on property values. Finally, the stated preference approaches are based on hypothetical markets and elicit people's WTP (or willingness to accept compensation - WTA) using carefully structured questionnaires. The most commonly acknowledged and widely used approaches are the Contingent Valuation (CV) method and the Choice Experiments (CE)/Conjoint Analysis. The CV has been the most commonly used non-market valuation method (for more details readers may refer to $[28,29])$. Finally, an alternative to revealed and stated preference methods, in cases of constrained budgets and timeframes, is the Benefit Transfer (or Value Transfer) method $[2,30]$. In reality, Benefit Transfer (BT) is not a valuation method. BT simply transfers "... existing data or information in settings other than for what it was originally collected ..." [31] by using value or function transfers or meta-data analysis. BT is increasingly being used in environmental valuation by scholars and organisations, although it cannot replace original research.

The review planning decided also on the data collection strategy (i.e. relevant databases, search strings and inclusion or exclusion criteria). As regards the data collection strategy, the Scopus database was preferred over Web of Science (WoS), because Scopus includes most of the journals indexed in WoS and has a larger number of exclusive journals than WoS in all fields [32]. Specifically, the Scopus database was selected because it includes over 75 million records and more than 24,600 titles in the areas of science, technology, medicine, social sciences, art and humanities. ${ }^{1}$ The Google

\footnotetext{
1 https://www.elsevier.com/_data/assets/pdf_file/0017/114533/Scopus_ GlobalResearch_Factsheet2019_FINAL_WEB.pdf.
} 
Table 1. The dataset publications.

\begin{tabular}{|c|c|c|}
\hline ID & Title & Reference \\
\hline 1 & Effect of Distance on the Preservation Value of Water Quality & [33] \\
\hline 2 & $\begin{array}{l}\text { An application of the Krutilla - Fisher model to appraising the benefits of green belt preservation versus site } \\
\text { development }\end{array}$ & [34] \\
\hline 3 & $\begin{array}{l}\text { Air quality and view degradations due to copper mining and milling: Preliminary analysis and cost estimates for } \\
\text { Green Valley, Arizona }\end{array}$ & [35] \\
\hline 4 & Reconciling private profitability and social costs: The case of clay mining in Sri Lanka & [36] \\
\hline 5 & Externalities from extraction of aggregates regulation by tax or land-use controls & [21] \\
\hline 6 & A contingent valuation study of the environmental costs of mining in the Brazilian amazon & [20] \\
\hline 7 & Economic approaches to valuing the environmental costs and benefits of mineral and aggregate extraction & [37] \\
\hline 8 & Valuing watershed quality improvements using conjoint analysis & [38] \\
\hline 9 & Contingent valuation of some externalities from mine dewatering & [39] \\
\hline 10 & Assessing the benefits of reclaiming urban quarries: A CVM analysis & [40] \\
\hline 11 & $\begin{array}{l}\text { Environmental economics and the mining industry: Monetary benefits of an abandoned quarry rehabilitation in } \\
\text { Greece }\end{array}$ & [41] \\
\hline 12 & The "battle of gold" under the light of green economics: A case study from Greece & [42] \\
\hline 13 & The hidden costs of relocating sand and gravel mines & [43] \\
\hline 14 & Estimating the economic benefits of acidic rock drainage clean up using cost shares & [44] \\
\hline 15 & Valuing acid mine drainage remediation in West Virginia: A hedonic modeling approach & [45] \\
\hline 16 & Efficient management of marine resources in conflict: An empirical study of marine sand mining, Korea & [46] \\
\hline 17 & The economic value of allocating water to post-mining lakes in East Germany & [47] \\
\hline 18 & Private and social costs of surface mine reforestation performance criteria & [48] \\
\hline 19 & Environmental accounting for pollution in the United States economy & [49] \\
\hline 20 & Evaluating and modeling ecosystem service loss of coal mining: A case study of Mentougou district of Beijing, China & [50] \\
\hline 21 & $\begin{array}{l}\text { Water eco-service assessment and compensation in a coal mining region - A case study in the Mentougou District in } \\
\text { Beijing }\end{array}$ & [51] \\
\hline 22 & Costs of abandoned coal mine reclamation and associated recreation benefits in Ohio & [52] \\
\hline 23 & External cost of coal based electricity generation: A tale of Ahmedabad city & [53] \\
\hline 24 & Externalities, NIMBY syndrome and marble quarrying activity & [54] \\
\hline 25 & Wind versus coal: Comparing the local economic impacts of energy resource development in Appalachia & [55] \\
\hline 26 & Externalities from lignite mining-related dust emissions & [56] \\
\hline 27 & Behind the life cycle of coal: Socio-environmental liabilities of coal mining in Cesar, Colombia & [57] \\
\hline 28 & Economic valuation of coal mining activity in Samarinda city, east Kalimantan, Indonesia & [58] \\
\hline 29 & $\begin{array}{l}\text { A methodological framework to assess the socio-economic impact of underground quarries: A case study from } \\
\text { Belgian Limburg }\end{array}$ & [59] \\
\hline 30 & $\begin{array}{l}\text { Economic valuation of mining heritage from a recreational approach: Application to the case of El Soplao Cave in } \\
\text { Spain (Geosite UR004) }\end{array}$ & [60] \\
\hline 31 & Estimation of external effects from the quarrying sector using the hedonic pricing method & [61] \\
\hline 32 & Externality costs of the coal-fuel cycle: The case of Kusile Power Station & [62] \\
\hline 33 & Life cycle cost estimation and environmental valuation of coal mine tailings management & [63] \\
\hline 34 & Valuing environmental health for informed policy-making & [64] \\
\hline 35 & $\begin{array}{l}\text { Valuing environmental impacts of mercury emissions from gold mining: Dollar per troy ounce estimates for twelve } \\
\text { open-pit, small-scale, and artisanal mining sites }\end{array}$ & [65] \\
\hline 36 & $\begin{array}{l}\text { An integrated framework to assess impacts on ecosystem services in LCA demonstrated by a case study of mining in } \\
\text { Chile }\end{array}$ & [66] \\
\hline 37 & $\begin{array}{l}\text { Perceived health risk, environmental knowledge, and contingent valuation for improving air quality: New evidence } \\
\text { from the Jinchuan mining area in China }\end{array}$ & [67] \\
\hline 38 & Changes in ecosystem service benefit in Soma lignite region of Turkey & [68] \\
\hline 39 & Habitat Equivalency Analysis, a framework for forensic cost evaluation of environmental damage & [69] \\
\hline 40 & $\begin{array}{l}\text { The value artificial lake ecosystems provide to recreational anglers: Implications for management of biodiversity and } \\
\text { outdoor recreation }\end{array}$ & [70] \\
\hline 41 & $\begin{array}{l}\text { Understanding social demand for sustainable nature conservation. The case of a protected natural space in South- } \\
\text { Eastern Spain }\end{array}$ & [71] \\
\hline 42 & Assessment of the external costs of life cycle of coal: The case study of southwestern China & [72] \\
\hline 43 & Is Mining an Environmental Disamenity? Evidence from Resource Extraction Site Openings & [73] \\
\hline 44 & $\begin{array}{l}\text { Model for assessing health damage from air pollution in quarrying area - Case study at Tan Uyen quarry, Ho Chi } \\
\text { Minh megapolis, Vietnam }\end{array}$ & [74] \\
\hline
\end{tabular}


Scholar was not originally searched since the search target comprises peer-reviewed articles only and not publications such as gray literature, presentations, keynotes, extended abstracts, etc. The initial Scopus search process started with a broad scoping of articles related to the environmental valuation of mining activities, using the following string: TITLE-ABS-KEY ((("environmental valu*" OR "benefit valu*" OR "environmental economics" OR externalities OR "natural resource damage assessment" OR "non-market valu*" OR "environmental cost"” OR "social cost*") AND ("mine" OR "mining" OR "quarry" OR "quarrying" OR "pit" OR "mining area" OR "quarry area" OR "quarry restoration" OR "mine restoration"))). A total of 968 records was originally returned. These records were limited to 200 using more specific keywords by adding the following expression to the previous string: AND ("contingent valuation" OR "hedonic pricing" OR "hedonic model*" OR "travel cost" OR "benefit transfer" OR "value transfer" OR "market value" OR "choice experiment" OR "choice model*" OR "external cost" OR "stated preference" OR "benefit-cost" OR "cost-benefit" OR conjoint OR "consumer surplus").

These articles were further screened based on the following criteria: (i) Papers published over the past four decades, i.e. 1980-2020; (ii) Papers published in peer-reviewed scientific journals; (iii) Papers published in English; and (iv) Papers applying nonmarket valuation techniques on specific case studies.

The first three filtering criteria were applied through the Scopus search. After removing publications before 1980, conference papers, book chapters, etc., and articles not written in English, the number of articles fulfilling the criteria for abstract reading was 161 . After reading the article abstract, 83 publications were excluded and 78 publications were selected and downloaded for full-text screening. Totally 41 publications fulfilled all the criteria. During the full-text screening, three additional publications were found by searching the reference lists of the identified articles and were added in the list. Hence, 44 articles were used in the analysis at the final stage, which are listed in Table 1. The search process is illustrated in Fig. 1.

In order to conduct the analysis, seventeen variables were defined during the reading of the publications included in the final set. These variables are described in Table 2.

The sampled studies follow different methodological approaches and do not share common monetary measures. Hence, to analyse the external costs or benefits of mining-related activities (i.e. exploitation or restoration works) and provide basic statistics and information for the monetary estimates of the sample, the original values underwent two different transformations. First, all the original values were converted to 2019 international dollar equivalents (int\$) using the Purchasing Power Parity (PPP) conversion factor and the USA Consumer Price Index (both indices were retrieved by the World Bank [75,76]), to account for price level differences between countries and adjustments to inflation rates, accordingly. Then, the transferred values were transformed to appropriate unit values after certain manipulations. More explicitly, in cases where appropriate information was available, e.g. total population affected, total or annual production of energy and non-energy minerals and total area affected, the annual or total estimated economic values were converted to unit values, e.g. int\$ per household and year $(\mathrm{HH})$, int\$ per hectare (ha), int\$

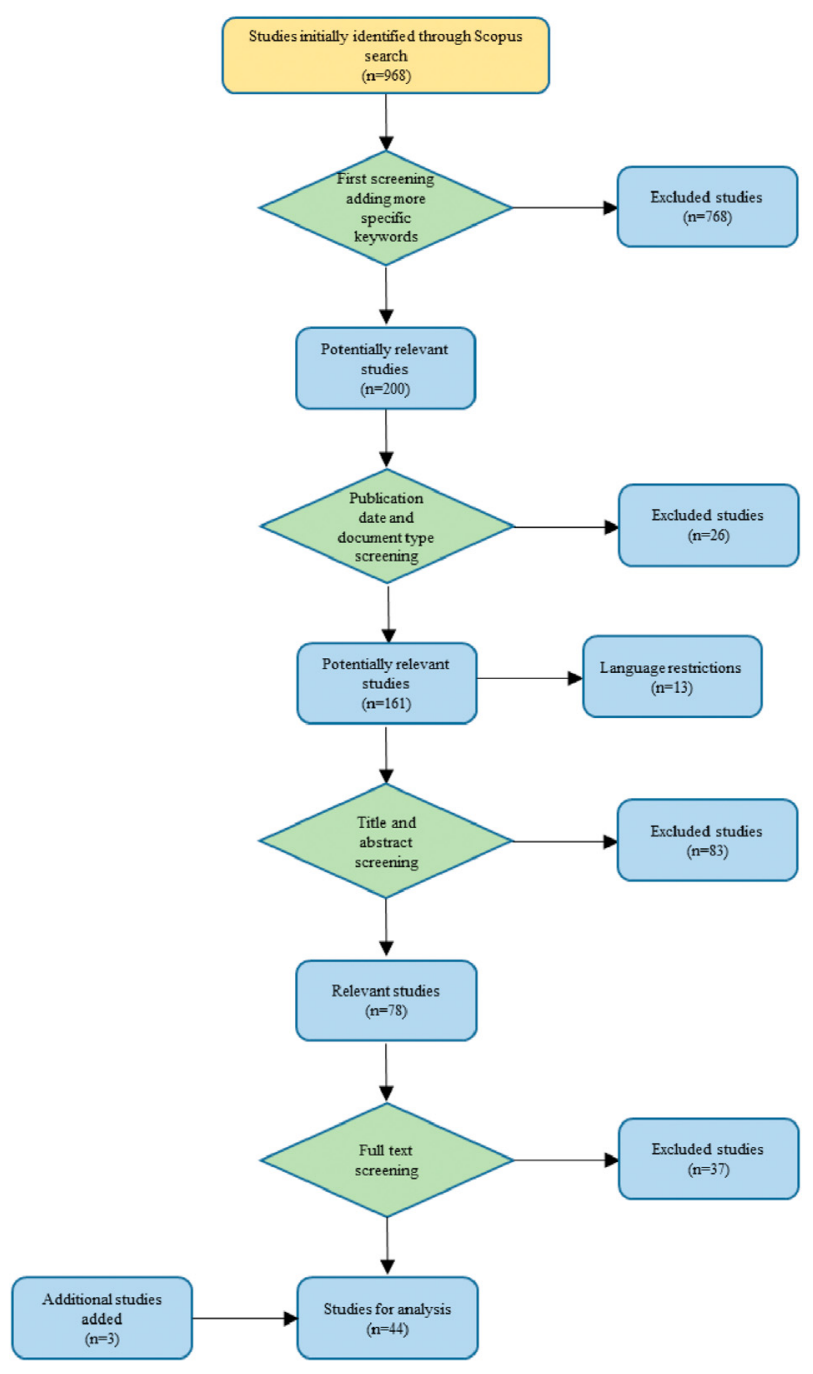

Fig. 1. Filtering of literature. 
Table 2. Variables used for the analysis.

\begin{tabular}{|c|c|c|}
\hline Variable & Description & Type \\
\hline Year of publication & Publication year of the article & Discrete \\
\hline Country of origin & Country of the valuation case studied & Nominal \\
\hline Journal & Title of the journal & Nominal \\
\hline Valuation method & Stated preference; Revealed preference; Non-demand method; Benefit transfer & Nominal \\
\hline Valuation approach & $\begin{array}{l}\text { Contingent valuation; Choice experiment; Hedonic pricing; Travel cost; Cost of } \\
\text { illness; Market price; Replacement cost; Dose-response; Damage cost avoided; } \\
\text { Mitigation cost; Opportunity cost }\end{array}$ & Nominal \\
\hline Type of value & Total value; use value; non-use value & Nominal \\
\hline Elicitation approach & Willingness to pay (WTP); Willingness to accept (WTA); Other & Nominal \\
\hline Data collection method & Face-to-face interviews; Telephone interviews; Mail survey; Web survey; n/a & Nominal \\
\hline Year of survey & Year of the data collection campaign & Discrete \\
\hline Original value & Original monetary estimate & Continuous \\
\hline Valuation units & E.g. per household, per person, per ton, etc. & Nominal \\
\hline Transformed value & Transformed monetary estimate & Continuous \\
\hline Transformed valuation units & Transformed valuation units & Nominal \\
\hline Mining project & E.g. quarry, metal mine, coal mine, etc. & Nominal \\
\hline Externalities & External costs; External benefits & Nominal \\
\hline Valuation item & $\begin{array}{l}\text { E.g. air quality, landscape quality, water quality, human health, soil quality, } \\
\text { recreation, housing market, etc. }\end{array}$ & Nominal \\
\hline Spatial scale & Local; Regional; National; Global & Nominal \\
\hline
\end{tabular}

per ton or $\mathrm{m}^{3}$, etc. Using this process, 156 unique monetary values derived from the review of the sampled studies.

\section{Results and discussion}

\subsection{Year of publication, country of origin and scientific journal}

As shown in Fig. 2 (a), five publications (11.4\%) were published before 2000 (and only one before 1990), twelve studies $(27.2 \%)$ were published between 2000 and 2009, and the rest twenty-seven studies $(61.4 \%)$ after 2010.

Further, the majority of publications have studied mining projects located at Europe (14 cases or $31.8 \%$ ), North America (11 cases or $25 \%$ ), Asia (10 cases or $22.7 \%$ ) and South America (5 cases or $11.4 \%)$. More specifically, externalities of mining projects have been studied in the USA (11 cases), Greece ( 5 cases), China ( 4 cases), UK ( 3 cases), Brazil ( 2 cases), Chile ( 2 cases), Germany ( 2 cases), Spain ( 2 cases), Australia (1 case), Belgium (1 case), Colombia (1 case), Czech Republic (1 case), India (1 case), Indonesia (1 case), Israel (1 case), Korea (1 case), South Africa (1 case), Sri Lanka (1 case), Turkey (1 case), and Vietnam (1 case). Further, one study examines externalities at the global scale.

The papers are published in journals of various disciplines (Table 3). As regards mining journals (i.e. journals that refer to mining activity in their statement mission), four papers have been published in "Resources Policy", two in "Environmental Geology" and one paper in each of the following

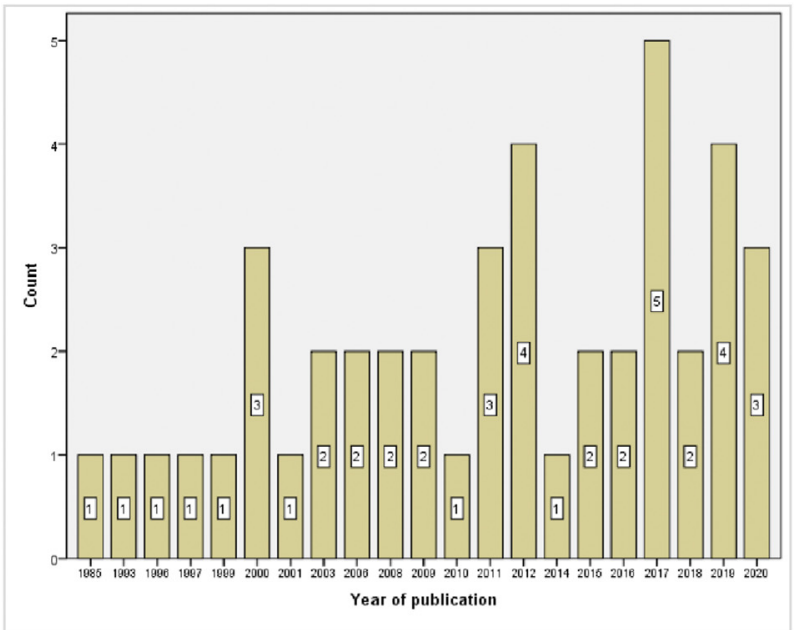

(a)

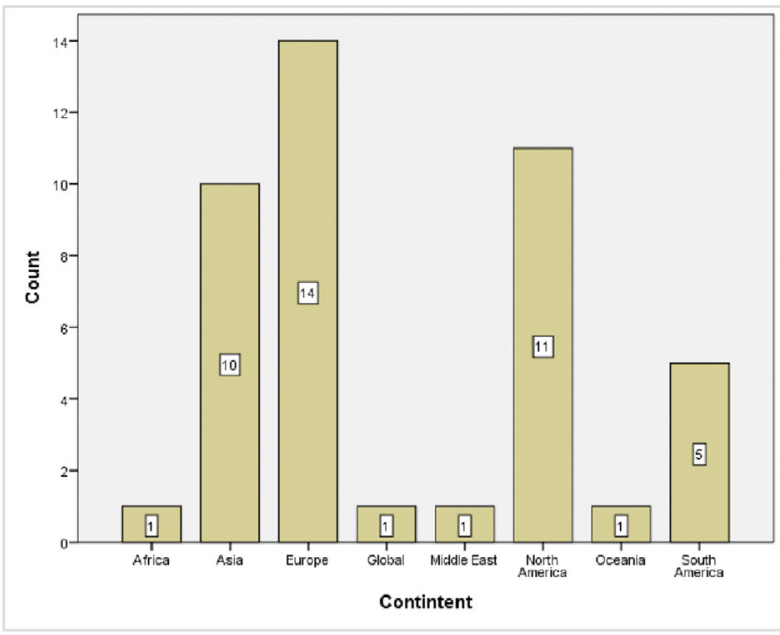

(b)

Fig. 2. Publication year (a) and continent of case studies (b). 
Table 3. Ranking of journals per papers published.

\begin{tabular}{|c|c|c|}
\hline Journal & Frequency & Percent \\
\hline Resources Policy & 4 & 9.1 \\
\hline Ecological Economics & 3 & 6.8 \\
\hline Energy Policy & 3 & 6.8 \\
\hline Journal of Environmental Management & 3 & 6.8 \\
\hline Ecological Complexity & 2 & 4.5 \\
\hline Ecosystem Services & 2 & 4.5 \\
\hline Environmental Geology & 2 & 4.5 \\
\hline Journal of Environmental Planning and Management & 2 & 4.5 \\
\hline American Economic Review & 1 & 2.3 \\
\hline Annals of Regional Science & 1 & 2.3 \\
\hline Economics and Human Biology & 1 & 2.3 \\
\hline Energies & 1 & 2.3 \\
\hline Environmental and Resource Economics & 1 & 2.3 \\
\hline Environmental Management & 1 & 2.3 \\
\hline Heliyon & 1 & 2.3 \\
\hline International Journal of Applied Engineering Research & 1 & 2.3 \\
\hline Journal for Nature Conservation & 1 & 2.3 \\
\hline Journal of Sustainable Mining & 1 & 2.3 \\
\hline Journal of Water Resources Planning and Management & 1 & 2.3 \\
\hline Land Economics & 1 & 2.3 \\
\hline Land Use Policy & 1 & 2.3 \\
\hline Landscape and Urban Planning & 1 & 2.3 \\
\hline Minerals and Energy & 1 & 2.3 \\
\hline Minerals and Energy - Raw Materials Report & 1 & 2.3 \\
\hline Natural Resources Research & 1 & 2.3 \\
\hline Project Appraisal & 1 & 2.3 \\
\hline Reviews on Environmental Health & 1 & 2.3 \\
\hline Science of the Total Environment & 1 & 2.3 \\
\hline South African Journal of Science & 1 & 2.3 \\
\hline Sustainability & 1 & 2.3 \\
\hline Water Resources Management & 1 & 2.3 \\
\hline
\end{tabular}

journals: "Journal of Sustainable Mining", "Minerals and Energy" and "Minerals and Energy - Raw Materials Report". This finding is related mainly to the affiliation of the authors. Specifically, only the authors of nine papers are affiliated with mining departments. The majority of the authors (i.e. 15 publications) are affiliated with environmental, agricultural and resource economics or business departments, followed by authors affiliated with environmental and civil engineering departments
(11 publications). The rest of the papers are authored by scholars affiliated with departments in agriculture, forestry, town planning, infrastructure and building management and policy.

\subsection{Valuation method, approaches and type of value}

This section presents the main findings in regards to the first research question (i.e. what are the main

Table 4. Valuation methods used in monetising mining-related externalities.

\begin{tabular}{lll}
\hline Valuation method & Frequency & Percent \\
\hline Stated preference methods & 16 & 34.1 \\
Non-demand curve methods & 11 & 25.0 \\
Benefit transfer method & 8 & 18.2 \\
Non-demand curve methods and Benefit transfer method & 4 & 9.1 \\
Revealed preference methods & 4 & 9.1 \\
Stated preference methods; Revealed preference methods & 1 & 2.3 \\
Demand and non-demand curve methods & 1 & 2.3 \\
\hline
\end{tabular}


Table 5. Valuation approaches used in monetising mining-related externalities.

\begin{tabular}{lll}
\hline Valuation approach & Frequency & Percent \\
\hline Contingent valuation & 10 & 22.7 \\
Benefit transfer & 8 & 18.2 \\
Choice experiment & 4 & 9.1 \\
Dose-response & 4 & 9.1 \\
Hedonic pricing & 3 & 6.8 \\
Avoided costs & 2 & 4.5 \\
Market price & 2 & 4.5 \\
Market price; Mitigation cost; Replacement cost; Benefit transfer & 2 & 4.5 \\
Conjoint analysis & 1 & 2.3 \\
Contingent valuation; Travel cost; Hedonic pricing & 1 & \\
Cost of illness; Productivity loss & 1 & 2.3 \\
Market price; Benefit transfer & 1 & 2.3 \\
Market price; Opportunity cost; Replacement cost & 1 \\
Market price; Opportunity cost; Replacement cost; Cost of illness & 1 \\
Market price; Replacement cost; Damage cost avoided; Contingent valuation; Hedonic pricing & 1 \\
Replacement cost; Benefit transfer & 1 \\
Travel cost & 1 & 2.3 \\
\end{tabular}

non-market valuation techniques used to monetising the environmental and social impacts of mining projects). More than $70 \%$ of the cases have employed primary methods (Table 4). Specifically, the authors have used stated preference approaches in fifteen cases (34.1\%) $[20,21,33-35,37-40,44,47,54,67,70,71]$, non-demand curve approaches in eleven cases $(25 \%)$ $[36,43,48-51,53,56,58,64,74]$, revealed preference approaches in four cases $(9.1 \%)[45,60,61,73]$ and combination of stated and revealed preference methods and demand and non-demand curve approaches in two cases [41,59]. Further, eight studies $(18.2 \%)$ were based on the benefit transfer method $[42,52,55,57,62,63,65,72]$ and four studies $(9.1 \%)$ combined the benefit transfer method with nondemand curve approaches $[58,66,68,69]$.

The following Table 5 presents the valuation approaches that have been employed in estimating external costs or benefits of mining projects.

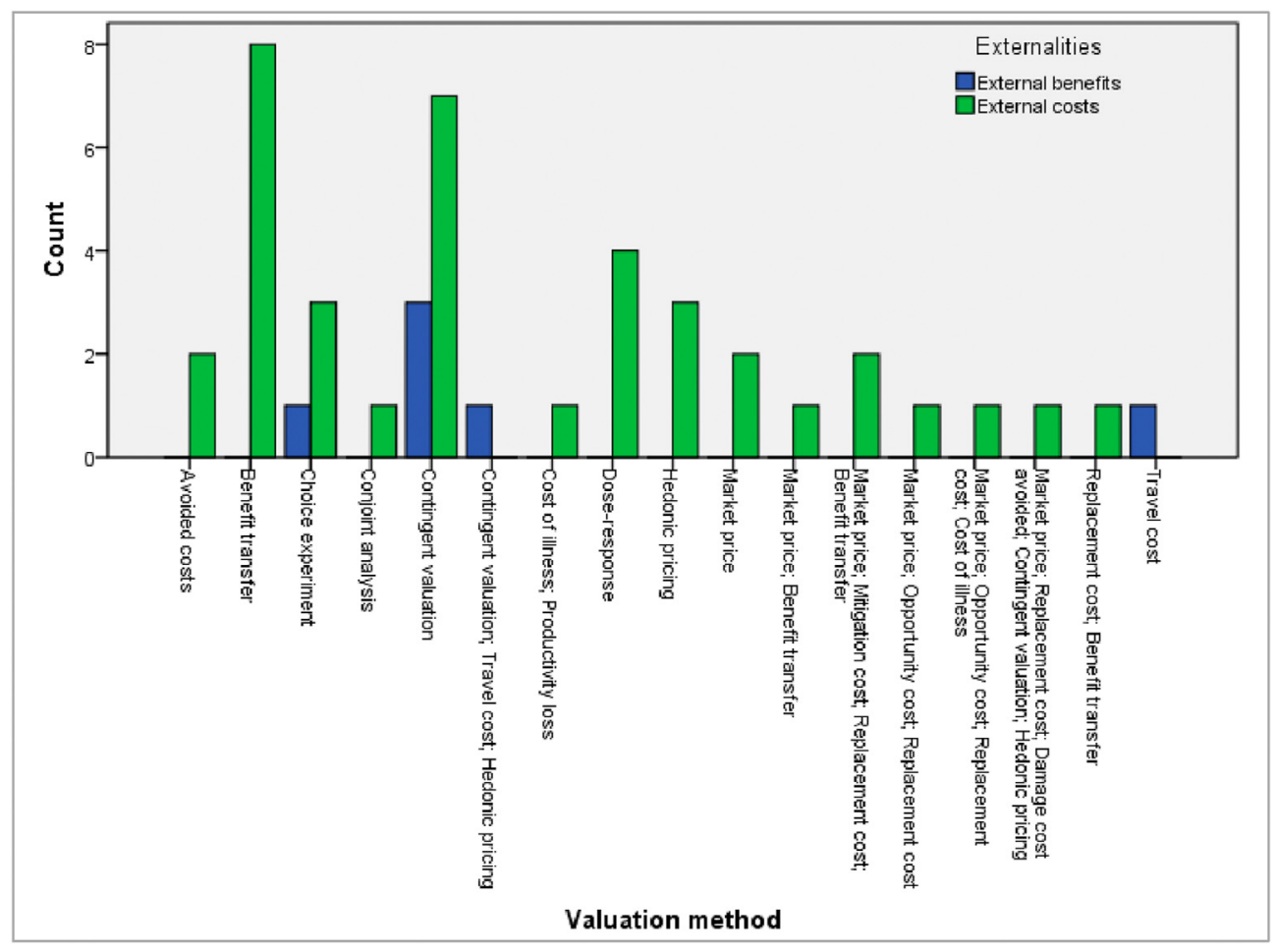

Fig. 3. Estimation of external costs or benefits per valuation approach. 
Table 6. Number of valuation studies per environmental medium, type of externality and valuation item.

\begin{tabular}{|c|c|c|c|c|}
\hline Environmental medium and valuation item & External benefits & External costs & Total & Reference \\
\hline Air & - & 7 & 7 & \\
\hline Health impacts & - & 5 & 5 & {$[56,64,65,67,74]$} \\
\hline $\begin{array}{l}\text { Health impacts; Agricultural production; } \\
\text { Infrastructure; Global warming }\end{array}$ & - & 1 & 1 & [53] \\
\hline $\begin{array}{l}\text { Health impacts; Agricultural production; } \\
\text { Timber production; } \\
\text { Infrastructure; Recreational services }\end{array}$ & - & 1 & 1 & [49] \\
\hline Air; Land & - & 2 & 2 & \\
\hline Air quality; Landscape quality & - & 1 & 1 & [35] \\
\hline $\begin{array}{l}\text { Health impacts; Agricultural } \\
\text { production; Infrastructure }\end{array}$ & - & 1 & 1 & [36] \\
\hline Air; Land; Water & - & 1 & 1 & \\
\hline Land quality; Air quality, Global warming & - & 1 & 1 & [63] \\
\hline Biota & - & 5 & 5 & \\
\hline Deforestation & - & 1 & 1 & [20] \\
\hline Forest ecosystem services & - & 2 & 2 & {$[68,69]$} \\
\hline Fisheries & - & 2 & 2 & {$[38,46]$} \\
\hline General & - & 10 & 10 & \\
\hline Environmental quality; Health impacts & - & 4 & 4 & {$[55,57,62,72]$} \\
\hline Environmental quality; Quality of life & - & 4 & 4 & {$[21,37,42,54]$} \\
\hline Property values & - & 2 & 2 & {$[61,73]$} \\
\hline Land & 3 & 5 & 8 & \\
\hline Agricultural production & - & 1 & 1 & [43] \\
\hline Property values; Infrastructure; & - & 1 & 1 & [59] \\
\hline \multicolumn{5}{|l|}{ Agricultural production; Recreational services } \\
\hline Protected areas & - & 1 & 1 & [71] \\
\hline Recreational services & 1 & - & 1 & [60] \\
\hline Recreational services; Environmental quality & 2 & - & 2 & {$[40,41]$} \\
\hline Restoration & - & 1 & 1 & [48] \\
\hline Timber production; Forest ecosystem services & - & 1 & 1 & [58] \\
\hline Land; Water & - & 1 & 1 & \\
\hline Water and land ecosystem services & - & 1 & 1 & {$[50]$} \\
\hline Water & 3 & 7 & 10 & \\
\hline Ecosystem services & - & 2 & 2 & {$[51,66]$} \\
\hline Recreational services & 3 & 3 & 6 & {$[33,34,39,47,52,70]$} \\
\hline Water quality & - & 2 & 2 & {$[44,45]$} \\
\hline Total & 6 & 38 & 44 & \\
\hline
\end{tabular}

Concerning the valuation approaches used, almost one-fourth of the studies have been conducted using the contingent valuation $[20,33-35,39,40,44,47,54,67]$, eight studies $(18.2 \%)$ have used the benefit transfer method $[42,52,55,57,62,63,65,72]$, four studies $(9.1 \%)$ have applied choice experiments $[21,37,70,71]$ and dose-response approaches $[53,56,64,74]$ respectively, three studies $(6.8 \%)$ have implemented the hedonic pricing approach $[45,61,73]$ and two studies $(4.5 \%)$ have used the market price $[46,49]$ and the avoided cost approaches [43,48], accordingly. The rest of the cases have employed different approaches, i.e. conjoint analysis [38] and travel cost [60], or a combination of approaches $[36,41,50,51,58,59,66,68,69]$.

In accordance with the valuation approaches, half of the studies have estimated use values $[36,43,45,46,48-53,55-57,60,61,64-66,70,72-74]$ and nineteen studies $(43.2 \%)$ have estimated the total economic value of the environmental good or service examined $[20,21,33-35,37,38,40-42,44,47,54,58,62,63,67,68,71]$. Finally, three cases $(6.9 \%)$ have combined different approaches and have estimated use and total economic values, separately $[39,59,69]$.

\subsection{Externalities monetised}

As far as the second research question is concerned, that is the main external costs or benefits of mining projects monetised employing non-market valuation, the vast majority of the studies (i.e. 38 or $86.4 \%$ ) have monetised externalities relating to negative impacts of mining on the ecosystem, the human health and the quality of life. Only six studies have monetised external benefits associated mainly with mining rehabilitation works. As illustrated in Fig. 3, external benefits have been measured using only the contingent valuation, 
Table 7. Number of valuation studies per mining type, type of externality and valuation approach.

\begin{tabular}{|c|c|c|c|c|}
\hline $\begin{array}{l}\text { Mining type/Valuation } \\
\text { method }\end{array}$ & External benefits & External costs & Total & References \\
\hline Aggregate quarrying & 2 & 7 & 9 & \\
\hline Avoided costs & & 1 & 1 & [43] \\
\hline Choice experiment & & 3 & 3 & {$[21,37,71]$} \\
\hline Contingent valuation & 1 & & 1 & [40] \\
\hline \multicolumn{5}{|l|}{$\begin{array}{l}\text { Travel cost; Hedonic } \\
\text { pricing }\end{array}$} \\
\hline Dose-response & & 1 & 1 & [74] \\
\hline Hedonic pricing & & 1 & 1 & [61] \\
\hline Market price; & & 1 & 1 & [59] \\
\hline \multicolumn{5}{|l|}{ Replacement cost; } \\
\hline \multicolumn{5}{|l|}{ Damage cost avoided; } \\
\hline \multicolumn{5}{|l|}{ Contingent valuation; } \\
\hline \multicolumn{5}{|l|}{ Hedonic pricing } \\
\hline Clay, sand, gravel mining & 1 & 3 & 4 & \\
\hline Choice experiment & 1 & & 1 & {$[70]$} \\
\hline Cost of illness; & & 1 & 1 & [36] \\
\hline \multicolumn{5}{|l|}{ Productivity loss } \\
\hline Market price & & 1 & 1 & [46] \\
\hline Replacement cost; & & 1 & 1 & [69] \\
\hline \multicolumn{5}{|l|}{ Benefit transfer } \\
\hline Coal mining & 1 & 16 & 17 & \\
\hline Avoided costs & & 1 & 1 & {$[48]$} \\
\hline Benefit transfer & & 6 & 6 & {$[52,55,57,62,63,72]$} \\
\hline Contingent valuation & 1 & 2 & 3 & {$[33,34,47]$} \\
\hline Dose-response & & 3 & 3 & {$[53,56,64]$} \\
\hline $\begin{array}{l}\text { Market price; Benefit } \\
\text { transfer }\end{array}$ & & 1 & 1 & {$[58]$} \\
\hline $\begin{array}{l}\text { Market price; Mitigation } \\
\text { cost; Replacement cost; }\end{array}$ & & 1 & 1 & [68] \\
\hline \multicolumn{5}{|l|}{ Benefit transfer } \\
\hline Market price; & & 1 & 1 & {$[50]$} \\
\hline \multicolumn{5}{|l|}{ Opportunity cost; } \\
\hline \multicolumn{5}{|l|}{ Replacement cost } \\
\hline Market price; & & 1 & 1 & [51] \\
\hline \multicolumn{5}{|l|}{ Opportunity cost; } \\
\hline \multirow{2}{*}{\multicolumn{5}{|c|}{$\begin{array}{l}\text { Replacement cost; Cost } \\
\text { of illness }\end{array}$}} \\
\hline & & & & \\
\hline Marble quarrying & & 1 & 1 & \\
\hline Contingent valuation & & 1 & 1 & [54] \\
\hline Metal mining & 2 & 8 & 10 & \\
\hline Benefit transfer & & 2 & 2 & {$[42,65]$} \\
\hline Conjoint analysis & & 1 & 1 & {$[38]$} \\
\hline Contingent valuation & 1 & 4 & 5 & {$[20,35,39,44,67]$} \\
\hline Hedonic pricing & & 1 & 1 & [45] \\
\hline Travel cost & 1 & & 1 & [60] \\
\hline Mining total & & 3 & 3 & \\
\hline Hedonic pricing & & 1 & 1 & [73] \\
\hline Market price & & 1 & 1 & [49] \\
\hline Market price; Mitigation & & 1 & 1 & [66] \\
\hline \multicolumn{5}{|l|}{ cost; Replacement cost; } \\
\hline \multicolumn{5}{|l|}{ Benefit transfer } \\
\hline Total & 6 & 38 & 44 & \\
\hline
\end{tabular}

Aggregate quarrying

Travel cost; Hedonic

Replacement cost;

Contingent valuation,

Clay, sand, gravel mining

Choice experiment

Cost of illness;

cost

Coal mining

Avoided cost

Contingent valuation

transfer

Benefit transfer

Replacement cos

Market price;

of illness

etal mining

2

Conjoint analysis

Contingent valuation

Hedonic pricing

Hedonic pricing

Market price

Benefit transfer 
Table 8. Number of valuation studies per mining type, type of externality and valuation item.

\begin{tabular}{|c|c|c|c|c|}
\hline $\begin{array}{l}\text { Mining type/Valuation } \\
\text { item }\end{array}$ & $\begin{array}{l}\text { External } \\
\text { benefits }\end{array}$ & $\begin{array}{l}\text { External } \\
\text { costs }\end{array}$ & Total & References \\
\hline Aggregate quarrying & 2 & 7 & 9 & \\
\hline Agricultural production & & 1 & 1 & [43] \\
\hline $\begin{array}{l}\text { Environmental quality; } \\
\text { Quality of life }\end{array}$ & \multicolumn{3}{|c|}{ Quality of life } & {$[21,37]$} \\
\hline Health impacts & & 1 & 1 & [74] \\
\hline Property values & & 1 & 1 & [61] \\
\hline Property values; & & 1 & 1 & [59] \\
\hline \multicolumn{5}{|l|}{ Infrastructure; } \\
\hline \multicolumn{5}{|l|}{ Agricultural production; } \\
\hline \multicolumn{5}{|l|}{ Recreational services } \\
\hline Protected areas & & 1 & 1 & {$[71]$} \\
\hline $\begin{array}{l}\text { Recreational services; } \\
\text { Environmental quality }\end{array}$ & \multicolumn{3}{|c|}{ Environmental quality } & {$[40,41]$} \\
\hline Clay, sand, gravel mining & 1 & 3 & 4 & \\
\hline Fisheries & & 1 & 1 & [46] \\
\hline $\begin{array}{l}\text { Forest ecosystem } \\
\text { services }\end{array}$ & & 1 & 1 & [69] \\
\hline Health impacts; & & 1 & 1 & [36] \\
\hline \multicolumn{5}{|l|}{ Agricultural production; } \\
\hline Recreational services & 1 & & 1 & [70] \\
\hline Coal mining & 1 & 16 & 17 & \\
\hline Ecosystem services & & 1 & 1 & [51] \\
\hline $\begin{array}{l}\text { Environmental quality; } \\
\text { Health impacts }\end{array}$ & & 4 & 4 & {$[55,57,62,72]$} \\
\hline $\begin{array}{l}\text { Forest ecosystem } \\
\text { services }\end{array}$ & & 1 & 1 & [68] \\
\hline Health impacts & & 2 & 2 & {$[56,64]$} \\
\hline Health impacts; & & 1 & 1 & [53] \\
\hline \multicolumn{5}{|l|}{ Agricultural production; } \\
\hline \multicolumn{5}{|l|}{$\begin{array}{l}\text { Infrastructure; Global } \\
\text { warming }\end{array}$} \\
\hline \multicolumn{5}{|l|}{$\begin{array}{l}\text { Land quality; Air } \\
\text { quality; Global warming }\end{array}$} \\
\hline Recreational services & 1 & 3 & 4 & {$[33,34,47,52]$} \\
\hline Restoration & & 1 & 1 & [48] \\
\hline Timber production; & & 1 & 1 & [58] \\
\hline \multicolumn{5}{|l|}{$\begin{array}{l}\text { Forest ecosystem } \\
\text { services }\end{array}$} \\
\hline $\begin{array}{l}\text { Water and land } \\
\text { ecosystem services }\end{array}$ & & 1 & 1 & [50] \\
\hline \multicolumn{5}{|l|}{ Marble quarrying } \\
\hline $\begin{array}{l}\text { Environmental quality; } \\
\text { Quality of life }\end{array}$ & \multicolumn{3}{|c|}{ Quality of life } & [54] \\
\hline Metal mining & 2 & 8 & 10 & \\
\hline $\begin{array}{l}\text { Air quality; Landscape } \\
\text { quality }\end{array}$ & & 1 & 1 & [35] \\
\hline Deforestation & & 1 & 1 & [20] \\
\hline Environmental quality; & & 1 & 1 & [42] \\
\hline \multicolumn{5}{|l|}{ Quality of life } \\
\hline Fisheries & & 1 & 1 & {$[38]$} \\
\hline Health impacts & & 2 & 2 & {$[65,67]$} \\
\hline Recreational services & 2 & & 2 & {$[39,60]$} \\
\hline Water quality & & 2 & 2 & {$[44,45]$} \\
\hline Mining total & & 3 & 3 & \\
\hline Ecosystem services & & 1 & 1 & [66] \\
\hline Health impacts; & & 1 & 1 & [49] \\
\hline \multicolumn{5}{|l|}{ Agricultural production; } \\
\hline \multicolumn{5}{|l|}{ Timber production; } \\
\hline \multicolumn{5}{|l|}{ Infrastructure; } \\
\hline \multicolumn{5}{|l|}{ Recreational services } \\
\hline Property values & & 1 & 1 & [73] \\
\hline Total & 6 & 38 & 44 & \\
\hline
\end{tabular}

choice experiment and travel cost approaches, i.e. demand curve methods.

As presented in Table 6, ten studies have estimated external costs (seven studies) or benefits (three studies) on water systems, eight studies have monetised impacts on land resources (three studies have estimated external benefits and five studies external costs, respectively), seven studies have assessed the external costs of mining activities on air quality, five studies have estimated external costs on biota, four studies external costs on more than one environmental media and ten studies have estimated external costs of environmental problems caused by mining activities in general.

Seventeen studies $(38.6 \%)$ refer to coal mining projects, ten studies $(22.7 \%)$ to metal mines, nine studies $(20.5 \%)$ to aggregate quarrying, four studies $(9.1 \%)$ to sand, gravel and clay mining and one study to marble quarrying. Further, ten studies $(22.7 \%)$ have monetised externalities of mining activities, in general. In more detail, the number of valuation studies per mining type, type of externality and valuation approach is presented in Table 7.

Also, Table 8 provides the analysis with regards to the number of valuation studies per mining type, type of externality and valuation item.

Concerning coal mining, sixteen studies deal with external costs and only one with external benefits. Particularly, two studies focus exclusively on health impacts; four studies examine impacts on health and the environment and one study monetises health impacts, losses in agricultural production, damages to infrastructure and contribution to global warming. Four studies are related to recreational services, two studies to forest ecosystem services, one study to water and land ecosystem services and one study to ecosystem services, more generally. Finally, one study contributed to the monetisation of restoration works and another one to the deterioration of land and air quality, as well as to the contribution to global warming. Six of the studies have been conducted using the benefit transfer method and two using a stated preference method, namely contingent valuation. The rest of the studies have employed non-demand curve methods, such as dose-response, market price, avoided cost, etc.

Eight out of the ten valuation studies in metal mining have estimated external costs related to health impacts (two cases), loss of recreational services (two cases), water pollution (two cases), air and landscape quality deterioration (one case), impacts on the environment and the quality of life (one case), deforestation (one case) and impacts on fisheries (one case). Finally, two studies have monetised benefits 
Table 9. Number of value estimates per unit value, mining type and valuation method.

\begin{tabular}{|c|c|c|c|c|c|c|}
\hline Unit value/Mining type & $\begin{array}{l}\text { Benefit } \\
\text { transfer }\end{array}$ & $\begin{array}{l}\text { Demand/ } \\
\text { Non-demand }\end{array}$ & Non-demand & $\begin{array}{l}\text { Non-demand/ } \\
\text { Benefit transfer }\end{array}$ & $\begin{array}{l}\text { Revealed } \\
\text { preference }\end{array}$ & $\begin{array}{l}\text { Stated } \\
\text { preference }\end{array}$ \\
\hline$\%$ loss in property value & & & & & & 3 \\
\hline Coal mining & & & & & & 3 \\
\hline$\%$ of added value & & & 2 & & & \\
\hline Mining total & & & 1 & & & \\
\hline $\begin{array}{l}\text { Total dimension stone } \\
\text { mining and quarrying }\end{array}$ & & & 1 & & & \\
\hline$\%$ reduction in tax & & & & & & 6 \\
\hline Aggregate quarrying & & & & & & 6 \\
\hline $\begin{array}{l}\% \text { premium in dwellings } \\
\text { owing to restoration } \\
\text { works }\end{array}$ & & & & & 1 & \\
\hline Aggregate quarrying & & & & & 1 & \\
\hline $\begin{array}{l}\% \text { increase in property } \\
\text { value for } 10 \% \text { increase } \\
\text { in distance from } \\
\text { quarries }\end{array}$ & & & & & 1 & \\
\hline Aggregate quarrying & & & & & 1 & \\
\hline$\%$ reduction in rent & & & & & 2 & \\
\hline Mining total & & & & & 2 & \\
\hline $\begin{array}{l}\text { loss in CS by single } \mathrm{HH} \\
\text { unit }\end{array}$ & & & & & & 1 \\
\hline Metal mining & & & & & & 1 \\
\hline $\begin{array}{l}\text { loss in property value by } \\
\text { single HH unit }\end{array}$ & & & & & 3 & \\
\hline Metal mining & & & & & 3 & \\
\hline per ha & 1 & & 5 & 4 & & \\
\hline Aggregate quarrying & & & 1 & & & \\
\hline Coal mining & 1 & & 4 & 2 & & \\
\hline $\begin{array}{l}\text { Sand, clay, gravel } \\
\text { mining }\end{array}$ & & & & 2 & & \\
\hline per ha.year & & & & 1 & & \\
\hline Coal mining & & & & 1 & & \\
\hline per $\mathrm{HH}$ loss in CS & & & & & & 1 \\
\hline Metal mining & & & & & & 1 \\
\hline $\begin{array}{l}\text { per HH.one-time- } \\
\text { payment }\end{array}$ & & & & & & 13 \\
\hline Aggregate quarrying & & & & & & 6 \\
\hline Metal mining & & & & & & 7 \\
\hline per HH.year & & & & & 2 & 15 \\
\hline Aggregate quarrying & & & & & & 3 \\
\hline Coal mining & & & & & & 1 \\
\hline Marble quarry & & & & & & 1 \\
\hline Metal mining & & & & & & 10 \\
\hline Mining total & & & & & 2 & \\
\hline per $\mathrm{kWh}$ & 2 & & 2 & & & \\
\hline Coal mining & 2 & & 2 & & & \\
\hline per $\mathrm{m}^{3}$ & & & 6 & & & \\
\hline Aggregate quarrying & & & 1 & & & \\
\hline $\begin{array}{l}\text { Sand, clay, gravel } \\
\text { mining }\end{array}$ & & & 5 & & & \\
\hline $\begin{array}{l}\text { per } \mathrm{m}^{3} \text { groundwater } \\
\text { supply }\end{array}$ & & & & 1 & & \\
\hline Mining total & & & & 1 & & \\
\hline per $\mathrm{m}^{3}$ seawater supply & & & & 1 & & \\
\hline Mining total & & & & 1 & & \\
\hline per oz $\mathrm{Au}$ & 5 & & & & & \\
\hline Metal mining & 5 & & & & & \\
\hline per person.year & & & & & & 11 \\
\hline Coal mining & & & & & & 6 \\
\hline Metal mining & & & & & & 3 \\
\hline
\end{tabular}

$\%$ loss in property value

reduction in tax

owing to restoration

Aggregate quarrying

increase in property

quarries

Mining total

oss in CS by single $\mathrm{HH}$

oss in property value by single $\mathrm{HH}$ unit

Metal mining

Aggregate quarrying

Coal mining

mining

per ha.year

Metal mining

per HH.one-time-

payment

Aggregate quarrying

Metal mining

Aggregate quarrying

Coal mining

Marble quarry

Metal mining

Coal mining

2

(continued on next page) 
Table 9. (continued)

\begin{tabular}{|c|c|c|c|c|c|c|}
\hline Unit value/Mining type & $\begin{array}{l}\text { Benefit } \\
\text { transfer }\end{array}$ & $\begin{array}{l}\text { Demand/ } \\
\text { Non-demand }\end{array}$ & Non-demand & $\begin{array}{l}\text { Non-demand/ } \\
\text { Benefit transfer }\end{array}$ & $\begin{array}{l}\text { Revealed } \\
\text { preference }\end{array}$ & $\begin{array}{l}\text { Stated } \\
\text { preference }\end{array}$ \\
\hline $\begin{array}{l}\text { Sand, clay, gravel } \\
\text { mining }\end{array}$ & & & & & & 2 \\
\hline per ton & 25 & & 26 & & & 2 \\
\hline Aggregate quarrying & & & & & & 2 \\
\hline Coal mining & 17 & & 26 & & & \\
\hline Metal mining & 8 & & & & & \\
\hline per ton $\mathrm{CO}_{2}$ & 1 & & & & & \\
\hline Coal mining & 1 & & & & & \\
\hline per trip & & & & & & 1 \\
\hline Metal mining & & & & & & 1 \\
\hline per unit of water & 1 & & & & & \\
\hline Coal mining & 1 & & & & & \\
\hline per visitor & 3 & & & & & \\
\hline Coal mining & 3 & & & & & \\
\hline per visitor CS benefit & & & & & 1 & \\
\hline Aggregate quarrying & & & & & 1 & \\
\hline $\begin{array}{l}\text { per year compensation to } \\
\text { a community fund }\end{array}$ & & & & & & 1 \\
\hline Marble quarry & & & & & & 1 \\
\hline $\begin{array}{l}\text { per year damages to } \\
\text { cultural values due to } \\
\text { collapse }\end{array}$ & & 1 & & & & \\
\hline Aggregate quarrying & & 1 & & & & \\
\hline $\begin{array}{l}\text { per year damages to } \\
\text { ecological values to } \\
\text { collapse }\end{array}$ & & 1 & & & & \\
\hline Aggregate quarrying & & 1 & & & & \\
\hline $\begin{array}{l}\text { per year direct damage } \\
\text { cost to collapse }\end{array}$ & & 1 & & & & \\
\hline Aggregate quarrying & & 1 & & & & \\
\hline $\begin{array}{l}\text { per year indirect damage } \\
\text { cost to collapse }\end{array}$ & & 1 & & & & \\
\hline Aggregate quarrying & & 1 & & & & \\
\hline $\begin{array}{l}\text { total recreational CS per } \\
\text { year }\end{array}$ & & & & & 2 & \\
\hline Aggregate quarrying & & & & & 1 & \\
\hline Metal mining & & & & & 1 & \\
\hline
\end{tabular}

associated with recreational activities. As regards the valuation method, eight studies employed demand curve approaches. More precisely, the sample includes six stated preference studies (five contingent valuation surveys and a conjoint analysis) and two revealed preference studies (namely hedonic pricing and travel cost). The rest two studies measured external benefits using the benefit transfer method.

Fourteen studies measure external costs (eleven cases) or benefits (three cases) from ornamental stone (one case) and aggregate quarries (nine cases) and sand, gravel and clay pits (four cases). Only two studies are concerned with impacts on human health (explicitly or among other externalities). Moreover, four studies examine adverse effects on the environment and the quality of life, three studies estimate the value of recreational services, two studies investigate the impact of the above- mentioned pits and quarries on property values and infrastructure and one study focuses on protected areas. Five studies examine, among other impacts, losses in agricultural production, fisheries and forest ecosystem services. In eight studies, the external costs of benefits have been valued using stated preference methods, i.e. contingent valuation (four cases) and choice experiment (also four cases). Further, four studies have employed revealed preference methods, such as the hedonic pricing (three cases) and the travel cost (one case). The rest of the studies have implemented non-demand curve approaches or the benefit transfer method.

Finally, three studies estimate the external costs of the mining sector, generally, employing non-demand curve methods (namely market price, mitigation cost and replacement cost), the benefit transfer method and the hedonic pricing method. 
Table 10. Average value estimates (in Int\$2019 or per cent) per unit value, mining type and valuation method.

\begin{tabular}{|c|c|c|c|c|c|c|}
\hline Unit value/Mining type & $\begin{array}{l}\text { Benefit } \\
\text { transfer }\end{array}$ & $\begin{array}{l}\text { Demand/ } \\
\text { Non-demand }\end{array}$ & Non-demand & $\begin{array}{l}\text { Non-demand/ } \\
\text { Benefit transfer }\end{array}$ & $\begin{array}{l}\text { Revealed } \\
\text { preference }\end{array}$ & $\begin{array}{l}\text { Stated } \\
\text { preference }\end{array}$ \\
\hline$\%$ loss in property value & & & & & & $13.6 \%$ \\
\hline Coal mining & & & & & & $13.6 \%$ \\
\hline$\%$ of added value & & & $95.5 \%$ & & & \\
\hline Mining total & & & $2.0 \%$ & & & \\
\hline $\begin{array}{l}\text { Total dimension stone } \\
\text { mining and quarrying }\end{array}$ & & & $189.0 \%$ & & & \\
\hline$\%$ reduction in tax & & & & & & $0.3 \%$ \\
\hline Aggregate quarrying & & & & & & $0.3 \%$ \\
\hline $\begin{array}{l}\% \text { premium in dwellings } \\
\text { owing to restoration } \\
\text { works }\end{array}$ & & & & & $26 \%$ & \\
\hline Aggregate quarrying & & & & & $26 \%$ & \\
\hline $\begin{array}{l}\% \text { increase in property } \\
\text { value for } 10 \% \text { increase } \\
\text { in distance from } \\
\text { quarries }\end{array}$ & & & & & $1 \%$ & \\
\hline Aggregate quarrying & & & & & $1 \%$ & \\
\hline$\%$ reduction in rent & & & & & $14 \%$ & \\
\hline Mining total & & & & & $14 \%$ & \\
\hline $\begin{array}{l}\text { loss in CS by single } \mathrm{HH} \\
\text { unit }\end{array}$ & & & & & & 13,798 \\
\hline Metal mining & & & & & & 13,798 \\
\hline $\begin{array}{l}\text { loss in property value } \\
\text { single HH unit }\end{array}$ & & & & & 9688 & \\
\hline Metal mining & & & & & 9688 & \\
\hline per ha & 4078 & & 4586 & 49,885 & & \\
\hline Aggregate quarrying & & & 21,191 & & & \\
\hline Coal mining & 4078 & & 435 & 12,465 & & \\
\hline $\begin{array}{l}\text { Sand, clay, gravel } \\
\text { mining }\end{array}$ & & & & 87,305 & & \\
\hline per ha.year & & & & 528 & & \\
\hline Coal mining & & & & 528 & & \\
\hline per $\mathrm{HH}$ loss in CS & & & & & & 3795 \\
\hline Metal mining & & & & & & 3795 \\
\hline $\begin{array}{l}\text { per HH.one-time- } \\
\text { payment }\end{array}$ & & & & & & 89 \\
\hline Aggregate quarrying & & & & & & 109 \\
\hline Metal mining & & & & & & 72 \\
\hline per HH.year & & & & & 588 & 303 \\
\hline Aggregate quarrying & & & & & & 1132 \\
\hline Coal mining & & & & & & 180 \\
\hline Marble quarry & & & & & & 34 \\
\hline Metal mining & & & & & & 93 \\
\hline Mining total & & & & & 588 & \\
\hline per $\mathrm{kWh}$ & 0.11 & & 0.01 & & & \\
\hline Coal mining & 0.11 & & 0.01 & & & \\
\hline per $\mathrm{m}^{3}$ & & & 1.53 & & & \\
\hline Aggregate quarrying & & & 3.40 & & & \\
\hline $\begin{array}{l}\text { Sand, clay, gravel } \\
\text { mining }\end{array}$ & & & 1.15 & & & \\
\hline $\begin{array}{l}\text { per } \mathrm{m}^{3} \text { groundwater } \\
\text { supply }\end{array}$ & & & & 0.15 & & \\
\hline Mining total & & & & 0.15 & & \\
\hline per $\mathrm{m}^{3}$ seawater supply & & & & 0.55 & & \\
\hline Mining total & & & & 0.55 & & \\
\hline per oz $\mathrm{Au}$ & 987.92 & & & & & \\
\hline Metal mining & 987.92 & & & & & \\
\hline per person.year & & & & & & 54.62 \\
\hline Coal mining & & & & & & 24.95 \\
\hline Metal mining & & & & & & 135.50 \\
\hline
\end{tabular}


Table 10. (continued)

\begin{tabular}{|c|c|c|c|c|c|c|}
\hline Unit value/Mining type & $\begin{array}{l}\text { Benefit } \\
\text { transfer }\end{array}$ & $\begin{array}{l}\text { Demand/ } \\
\text { Non-demand }\end{array}$ & Non-demand & $\begin{array}{l}\text { Non-demand/ } \\
\text { Benefit transfer }\end{array}$ & $\begin{array}{l}\text { Revealed } \\
\text { preference }\end{array}$ & $\begin{array}{l}\text { Stated } \\
\text { preference }\end{array}$ \\
\hline $\begin{array}{l}\text { Sand, clay, gravel } \\
\text { mining }\end{array}$ & & & & & & 22.33 \\
\hline per ton & 16.70 & & 0.94 & & & 1.59 \\
\hline Aggregate quarrying & & & & & & 1.59 \\
\hline Coal mining & 23.40 & & 0.94 & & & \\
\hline Metal mining & 2.46 & & & & & \\
\hline per ton $\mathrm{CO}_{2}$ & 7.93 & & & & & \\
\hline Coal mining & 7.93 & & & & & \\
\hline per trip & & & & & & 23.73 \\
\hline Metal mining & & & & & & 23.73 \\
\hline per unit of water & 2.18 & & & & & \\
\hline Coal mining & 2.18 & & & & & \\
\hline per visitor & 17.55 & & & & & \\
\hline Coal mining & 17.55 & & & & & \\
\hline per visitor CS benefit & & & & & 1.94 & \\
\hline Aggregate quarrying & & & & & 1.94 & \\
\hline $\begin{array}{l}\text { per year compensation to } \\
\text { a community fund }\end{array}$ & & & & & & 48,751 \\
\hline Marble quarry & & & & & & 48,751 \\
\hline $\begin{array}{l}\text { per year damages to } \\
\text { cultural values due to } \\
\text { collapse }\end{array}$ & & 171 & & & & \\
\hline Aggregate quarrying & & 171 & & & & \\
\hline $\begin{array}{l}\text { per year damages to } \\
\text { ecological values to } \\
\text { collapse }\end{array}$ & & 306 & & & & \\
\hline Aggregate quarrying & & 306 & & & & \\
\hline $\begin{array}{l}\text { per year direct damage } \\
\text { cost to collapse }\end{array}$ & & 116,209 & & & & \\
\hline Aggregate quarrying & & 116,209 & & & & \\
\hline $\begin{array}{l}\text { per year indirect damage } \\
\text { cost to collapse }\end{array}$ & & 446,182 & & & & \\
\hline Aggregate quarrying & & 446,182 & & & & \\
\hline $\begin{array}{l}\text { total recreational CS per } \\
\text { year }\end{array}$ & & & & & $1,628,291$ & \\
\hline Aggregate quarrying & & & & & $1,299,859$ & \\
\hline Metal mining & & & & & $1,956,722$ & \\
\hline
\end{tabular}

\subsection{Monetary estimates}

In order to answer the third research question concerning the economic evidence (i.e. valuation estimates) on the external costs or benefits of mining projects, the original values were transformed to appropriate unit values, in cases where necessary information was available. This process resulted in 156 unique monetary values. The following Table 9 presents the number of value estimates per valuation method, transformed unit value and mining type.

In total, 15 values are expressed in percent form (e.g. percentage loss in property value, percentage reduction in taxes paid by the affected population, etc.), 11 values in Int\$ per ha or per ha and year, 35 values in Int\$ per HH either per year or as one-timepayment, 4 values in Int\$ per $\mathrm{kWh}, 15$ values in Int\$ per person or visitor, 64 values in Int $\$$ per ton or $\mathrm{m}^{3}$ of mineral production, 7 values in total losses or CS per year, 3 values in units of water consumed by mining activities, 1 value in Int\$ per trip and 1 value in Int\$ per ton $\mathrm{CO}_{2}$ emitted by mining activities.

Further, Table 10 provides average value estimates (in Int $\$ 2019$ or percent) per transformed unit value, mining type and valuation method.

According to Table 10, there is a wide range in the estimates. For instance, the monetary values per $\mathrm{HH}$ and year range from Int $\$ 2.3$ (non-use value WTP for improvements in watershed quality in the USA) to Int $\$ 2418.6$ (WTA per year for 314 days with noise, dust and mud disturbance from quarrying activities in the UK), while the per $\mathrm{HH}$ one-time-payment monetary values range between Int $\$ 17.6$ (one-time payment for the removal of a drainage culvert from a stream in the USA) and Int $\$ 140.9$ (one-time tax 
payment for the rehabilitation of an urban abandoned quarry of 20 ha in Greece). The external costs per ton of mineral production span from Int $\$ 0.001$ (externalities of coal mining on several ecosystem services in China) to Int $\$ 228.8$ (socio-environmental liabilities of coal mining in a region of Colombia). Also, the external costs of gold mining due to mercury emissions range from Int $\$ 1.1$ per troy ounce (for open-pit gold mines in Nevada, USA, where imposed controls on smelting operations have drastically reduced mercury emissions) to Int $\$ 3510$ per troy ounce (for artisanal and small-scale mining where mercury is applied to the whole ore). The last estimates come from the same study and derived following an identical methodology.

Considering the above-mentioned examples, it is evident that the divergence in the estimates is attributed to several factors, with the most important being the valuation approach used in each case study, the economic value estimated (i.e. total, use or non-use value), the assumptions adopted by the authors (e.g. the adverse impacts considered by the study, the influence range of these impacts and, consequently, the size of the population affected) and, most importantly, the particular characteristics of each mining project and of the surrounding natural and man-made environment. Therefore, in benefit transfer applications, the selection of previous valuation studies for calculating monetary costs or benefits for a new site should be done with extreme caution.

\section{Conclusions}

Environmental economics is increasingly being used to meet the demand for information on nonmarket values of environmental resources and services for socio-economic project appraisals, environmental liability estimates and design of MBIs. These developments have already affected the mining industry at a great extent. As a result, tenths of research papers have been published in refereed journals. Nevertheless, a systematic review of these publications has not been carried out, so far.

This paper aims to fill this gap in the literature by investigating: (i) the main non-market valuation techniques used to monetising the environmental and social impacts of mining projects; (ii) the main external costs or benefits of mining projects monetised; and (iii) the monetary estimates of miningrelated externalities. The analysis shows that practically all economic valuation techniques (demand and non-demand curve approaches and the benefit transfer method) have been used to assess in monetary terms the potential economic, environmental, health and quality of life impacts from coal and metal mines, aggregate and ornamental stone quarries and sand, gravel and clay pits. Moreover, the findings from the statistical analysis of the (transferred and transformed) monetary values reveal a wide range of estimates. The scale of the monetary values varies not only by valuation method (or the specific methodological assumptions adopted by the researchers) but also by the type of the mining activity (e.g. metal mine, aggregate quarry, etc.), and the specific characteristics of the mining projects (e.g. size of the activity, location of the project - national park, urban area, urban area, etc.). Finally, the systematic review draws directions for future research. The analysis of the published studies indicates areas of limited availability of estimates or high heterogeneity between the available estimates. In this direction, future valuation efforts should aim at filling these gaps by conducting valuation surveys for a wide variety of mining projects and with different valuation methods.

\section{Ethical statement}

The authors state that the research was conducted according to ethical standards.

\section{Funding body}

None.

\section{Conflicts of interest}

None declared.

\section{References}

[1] Pearce D. An intellectual history of environmental economics. Annu Rev Energy Environ 2002. https://doi.org/ 10.1146/annurev.energy.27.122001.083429.

[2] Damigos D. An overview of environmental valuation methods for the mining industry, vol. 14; 2006. https:// doi.org/10.1016/j.jclepro.2004.06.005.

[3] Navrud S, Pruckner GJ. Environmental valuation - to use or not to use? Environ Resour Econ 1997. https://doi.org/ 10.1023/A:1026449715284.

[4] Atkinson G, Groom B, Hanley N, Mourato S. Environmental valuation and benefit-cost analysis in U.K. Policy. J BenefitCost Anal 2018. https://doi.org/10.1017/bca.2018.6.

[5] Andersson H. Application of BCA in europe-experiences and challenges. J Benefit-Cost Anal 2018. https://doi.org/10.1017/ bca.2018.5.

[6] Belli P, Anderson J, Barnum H, Dixon J, Tan J-P. HANDBOOK ON ECONOMIC ANALYSIS OF INVESTMENT OPERATIONS operational core services network learning and leadership center. 1998.

[7] Bonnieux F, Rainelli P. Contingent valuation methodology and the EU institutional framework. 1999.

[8] Florio M, Morretta V, Willak W. Cost-benefit analysis and European union cohesion policy: economic versus financial 
returns in investment project appraisal. J Benefit-Cost Anal 2018. https://doi.org/10.1017/bca.2018.4.

[9] European Commission. Guide to cost-benefit analysis of investment projects: economic appraisal tool for cohesion policy 2014-2020. https://doi.org/10.2776/97516; 2014.

[10] Hanemann WM, Strand IE. Natural resource damage assessment: economic implications for fisheries management. Am J Agric Econ 1993. https://doi.org/10.2307/1243452.

[11] Jones CA. Compensation for natural resource damages from oil spills: a comparison of US law and international conventions. Int J Environ Pollut 1999. https://doi.org/10.1504/ IJEP.1999.002251.

[12] Bullock C, O'Shea R. Valuing environmental damage remediation and liability using value estimates for ecosystem services. J Environ Plann Manag 2016. https://doi.org/ 10.1080/09640568.2015.1085842.

[13] Stavins RN. Chapter 9 - experience with market-based environmental policy instruments. In: Mäler K-G, Vincent JR, editors. Environ. Degrad. Institutional responses, vol. 1. Elsevier; 2003. p. 355-435. https://doi.org/10.1016/ S1574-0099(03)01014-3.

[14] European Environment Agency. Market-based instruments for environmental policy in Europe. 2005.

[15] Hendryx M. The public health impacts of surface coal mining. Extr Ind Soc 2015. https://doi.org/10.1016/ j.exis.2015.08.006.

[16] Dudka S, Adriano DC. Environmental impacts of metal ore mining and processing: a review. J Environ Qual 1997. https://doi.org/10.2134/jeq1997.00472425002600030003x.

[17] Matschullat J, Gutzmer J. Mining and its environmental impacts. Environ Geol 2012. https://doi.org/10.1007/978-14939-8787-0_205.

[18] Ingram $\mathrm{V}$, Tieguhong JC, Schure J, Nkamgnia E, Tadjuidje MH. Where artisanal mines and forest meet: socioeconomic and environmental impacts in the Congo Basin. Nat Resour Forum 2011;35:304-20. https://doi.org/10.1111/ j.1477-8947.2011.01408.x.

[19] Carson RT, Wilks L, Imber D. Valuing the preservation of Australia's kakadu conservation zone. Oxf Econ Pap; 1994. https://doi.org/10.1093/oep/46.Supplement_1.727.

[20] Mendonça AF, Tilton JE. A contingent valuation study of the environmental costs of mining in the brazilian amazon. Miner Energy - Raw Mater Rep 2000;15:21-32. https:// doi.org/10.1080/14041040009362570.

[21] Willis KG, Garrod GD. Externalities from extraction of aggregates regulation by tax or land-use controls. Resour Pol 1999;25:77-86. https://doi.org/10.1016/S0301-4207(99)000124.

[22] Liberati A, Altman DG, Tetzlaff J, Mulrow C, Gøtzsche PC, Ioannidis JPA, et al. The PRISMA statement for reporting systematic reviews and meta-analyses of studies that evaluate health care interventions: explanation and elaboration. J Clin Epidemiol 2009. https://doi.org/10.1016/ j.jclinepi.2009.06.006.

[23] Palmatier RW, Houston MB, Hulland J. Review articles: purpose, process, and structure. J Acad Market Sci 2018. https://doi.org/10.1007/s11747-017-0563-4.

[24] Snyder H. Literature review as a research methodology: an overview and guidelines. J Bus Res 2019. https://doi.org/ 10.1016/j.jbusres.2019.07.039.

[25] Berrang-Ford L, Pearce T, Ford JD. Systematic review approaches for climate change adaptation research. Reg Environ Change 2015. https://doi.org/10.1007/s10113-014-0708-7.

[26] Pullin A, Frampton G, Livoreil B, Petrokofsky G. Collaboration for environmental evidence. Guidelines and standards for evidence synthesis in environmental management Version 5.0. 2018.

[27] Xiao Y, Watson M. Guidance on conducting a systematic literature review. J Plann Educ Res 2019. https://doi.org/ 10.1177/0739456X17723971.
[28] Bateman IJ. Valuing preferences regarding environmental change. SAGE Handb Environ Soc 2012. https://doi.org/ 10.4135/9781848607873.n10.

[29] Haab T, McConnell K. Valuing environmental and natural resources. https://doi.org/10.4337/9781843765431; 2013.

[30] Richardson L, Loomis J, Kroeger T, Casey F. The role of benefit transfer in ecosystem service valuation. Ecol Econ 2015. https://doi.org/10.1016/j.ecolecon.2014.02.018.

[31] Rosenberger RS, Loomis JB. Benefit transfer. In: Champ PA, Boyle KJ, Brown TC, editors. A prim. Nonmarket valuat. Boston: Kluwer Academic Publishers; 2003. p. 395-444. https://doi.org/10.1007/978-94-007-0826-6_12.

[32] Mongeon P, Paul-Hus A. The journal coverage of Web of Science and Scopus: a comparative analysis. Scientometrics 2016. https://doi.org/10.1007/s11192-015-1765-5.

[33] Sutherland RJ, Walsh RG. Effect of distance on the preservation value of water quality (coal mining). Land Econ 1985 61(3)281-91. https://doi.org/10.2307/3145843.

[34] Willis KG, Nelson GB, Bye AB, Peacock G. An application of the krutilla - Fisher model to appraising the benefits of green belt preservation versus site development. J Environ Plann Manag 1993;36:73-90. https://doi.org/10.1080/ 09640569308711928.

[35] Kim H-S, Harris D. Air quality and view degradations due to copper mining and milling: preliminary analysis and cost estimates for Green Valley, Arizona. Nat Resour Res 1996;5: 91-102. https://doi.org/10.1007/BF02257583.

[36] Ranasinghe M. Reconciling private profitability and social costs: the case of clay mining in Sri Lanka. Proj Apprais 1997; 12:31-41. https://doi.org/10.1080/02688867.1997.9727035.

[37] Garrod GD, Willis KG. Economic approaches to valuing the environmental costs and benefits of mineral and aggregate extraction. Miner Energy - Raw Mater Rep 2000. https:// doi.org/10.1080/14041040009362569.

[38] Farber S, Griner B. Valuing watershed quality improvements using conjoint analysis. Ecol Econ 2000;34:63-76. https:// doi.org/10.1016/S0921-8009(00)00153-1.

[39] Huszar EJ, Netusil NR, Shaw WD. Contingent valuation of some externalities from mine dewatering. J Water Resour Plann Manag 2001;127:369-77. https://doi.org/10.1061/ (ASCE)0733-9496(2001)127:6(369).

[40] Damigos D, Kaliampakos D. Assessing the benefits of reclaiming urban quarries: a CVM analysis. Landsc Urban Plann 2003;64. https://doi.org/10.1016/S0169-2046(02)00243-8.

[41] Damigos D, Kaliampakos D. Environmental economics and the mining industry: monetary benefits of an abandoned quarry rehabilitation in Greece. Environ Geol 2003. https:// doi.org/10.1007/s00254-003-0774-5.

[42] Damigos D, Kaliampakos D. The "battle of gold" under the light of green economics: a case study from Greece. Environ Geol 2006. https://doi.org/10.1007/s00254-006-0201-9.

[43] Jaeger WK. The hidden costs of relocating sand and gravel mines. Resour Pol 2006;31:146-64. https://doi.org/10.1016/ j.resourpol.2006.12.003.

[44] Strong A, Flores NE. Estimating the economic benefits of acidic rock drainage clean up using cost shares. Ecol Econ 2008;65:348-55. j.ecolecon.2007.06.021

[45] Williamson JM, Thurston HW, Heberling MT. Valuing acid mine drainage remediation in West Virginia: a hedonic modeling approach. Ann Reg Sci 2008;42:987-99. https:// doi.org/10.1007/s00168-007-0189-4.

[46] Kim T -g. Efficient management of marine resources in conflict: an empirical study of marine sand mining, Korea. J Environ Manag 2009;91:78-86. https://doi.org/10.1016/ j.jenvman.2009.07.006.

[47] Lienhoop N, Messner F. The economic value of allocating water to post-mining lakes in East Germany. Water Resour Manag 2009;23:965-80. https://doi.org/10.1007/s11269-0089309-x. 
[48] Sullivan J, Amacher GS. Private and social costs of surface mine reforestation performance criteria. Environ Manag 2010;45:311-9. https://doi.org/10.1007/s00267-009-9395-4.

[49] Muller NZ, Mendelsohn R, Nordhaus W. Environmental accounting for pollution in the United States economy. Am Econ Rev 2011;101:1649-75. https://doi.org/10.1257/ aer.101.5.1649.

[50] Li F, Liu X, Zhao D, Wang B, Jin J, Hu D. Evaluating and modeling ecosystem service loss of coal mining: a case study of Mentougou district of Beijing, China. Ecol Complex 2011; 8:139-43. https://doi.org/10.1016/j.ecocom.2011.01.002.

[51] Bai Y, Wang R, Jin J. Water eco-service assessment and compensation in a coal mining region - a case study in the Mentougou District in Beijing. Ecol Complex 2011. https:// doi.org/10.1016/j.ecocom.2011.01.003.

[52] Mishra SK, Hitzhusen FJ, Sohngen BL, Guldmann J-M. Costs of abandoned coal mine reclamation and associated recreation benefits in Ohio. J Environ Manag 2012;100:52-8. https://doi.org/10.1016/j.jenvman.2012.01.021.

[53] Mahapatra D, Shukla P, Dhar S. External cost of coal based electricity generation: a tale of Ahmedabad city. Energy Pol 2012;49:253-65. https://doi.org/10.1016/j.enpol.2012.06.014.

[54] Pelekasi T, Menegaki M, Damigos D. Externalities, NIMBY syndrome and marble quarrying activity. J Environ Plann Manag 2012;55:1192-205. https://doi.org/10.1080/ 09640568.2011.638047.

[55] Collins AR, Hansen E, Hendryx M. Wind versus coal: comparing the local economic impacts of energy resource development in Appalachia. Energy Pol 2012;50:551-61. https://doi.org/10.1016/j.enpol.2012.08.001.

[56] Papagiannis A, Roussos D, Menegaki M, Damigos D. Externalities from lignite mining-related dust emissions. Energy Pol 2014;74:414-24. https://doi.org/10.1016/ j.enpol.2014.08.026.

[57] Cardoso A. Behind the life cycle of coal: socio-environmental liabilities of coal mining in Cesar, Colombia. Ecol Econ 2015. https://doi.org/10.1016/j.ecolecon.2015.10.004.

[58] Prasodjo E, Sitorus SRP, Pertiwi S, Putri EIK. Economic valuation of coal mining activity in Samarinda city, east Kalimantan, Indonesia. Int J Appl Eng Res 2015;10:26347-62.

[59] Sergeant A, Poesen J, Duchateau P, Vranken L. A methodological framework to assess the socio-economic impact of underground quarries: a case study from Belgian Limburg. Sci Total Environ 2016;541:559-69. https://doi.org/ 10.1016/j.scitotenv.2015.09.079.

[60] Pérez-álvarez R, Torres-Ortega S, Díaz-Simal P, HusillosRodríguez R, De Luis-Ruiz JM. Economic valuation of mining heritage from a recreational approach: application to the case of El Soplao Cave in Spain (Geosite UR004). Sustain Times 2016. https://doi.org/10.3390/su8020185.

[61] Lavee D, Bahar S. Estimation of external effects from the quarrying sector using the hedonic pricing method. Land Use Pol 2017. https://doi.org/10.1016/ j.landusepol.2017.10.005.

[62] Nkambule NP, Blignaut JN. The external costs of coal mining: the case of collieries supplying Kusile power station.
J Energy South Afr 2012;23:85-93. https://doi.org/10.17159/ 2413-3051/2012/v23i4a3181.

[63] Adiansyah JS, Rosano M, Biswas W, Haque N. Life cycle cost estimation and environmental valuation of coal mine tailings management. J Sustain Min 2017;16:114-25. https://doi.org/ 10.1016/j.jsm.2017.10.004.

[64] Máca V, Melichar J, Ščasný M, Kohlová MB. Valuing environmental health for informed policy-making. Rev Environ Health 2017. https://doi.org/10.1515/reveh-2016-0035.

[65] Gulley AL. Valuing environmental impacts of mercury emissions from gold mining: dollar per troy ounce estimates for twelve open-pit, small-scale, and artisanal mining sites. Resour Pol 2017;52:266-72. https://doi.org/10.1016/ j.resourpol.2017.03.009.

[66] Blanco CF, Marques A, van Bodegom PM. An integrated framework to assess impacts on ecosystem services in LCA demonstrated by a case study of mining in Chile. Ecosyst Serv 2018. https://doi.org/10.1016/j.ecoser.2017.11.011.

[67] Li Z, Hu B. Perceived health risk, environmental knowledge, and contingent valuation for improving air quality: new evidence from the Jinchuan mining area in China. Econ Hum Biol 2018. https://doi.org/10.1016/j.ehb.2018.07.007.

[68] Demirbugan A. Changes in ecosystem service benefit in Soma lignite region of Turkey. Resour Pol 2019;64. https:// doi.org/10.1016/j.resourpol.2019.101522.

[69] Pavanelli DD, Voulvoulis N. Habitat Equivalency Analysis, a framework for forensic cost evaluation of environmental damage. Ecosyst Serv 2019. https://doi.org/10.1016/ j.ecoser.2019.100953.

[70] Meyerhoff J, Klefoth T, Arlinghaus R. The value artificial lake ecosystems provide to recreational anglers: implications for management of biodiversity and outdoor recreation. J Environ Manag 2019;252. https://doi.org/10.1016/ j.jenvman.2019.109580.

[71] Alcon F, Albaladejo-García JA, Zabala JA, Marín-Miñano C, Martínez-Paz JM. Understanding social demand for sustainable nature conservation. The case of a protected natural space in South-Eastern Spain. J Nat Conserv 2019. https:// doi.org/10.1016/j.jnc.2019.125722.

[72] Wang X, Wang L, Chen J, Zhang S, Tarolli P. Assessment of the external costs of life cycle of coal: the case study of southwestern China. Energies 2020;13. https://doi.org/ 10.3390/en13154002.

[73] Rivera NM. Is mining an environmental disamenity? Evidence from resource extraction site openings. Environ Resour Econ 2020;75:485-528. https://doi.org/10.1007/ s10640-019-00397-w.

[74] Bui LT, Nguyen PH, Nguyen DCM. Model for assessing health damage from air pollution in quarrying area - case study at Tan Uyen quarry. Ho Chi Minh megapolis, Vietnam Heliyon 2020;6. https://doi.org/10.1016/j.heliyon.2020.e05045.

[75] World Bank. PPP conversion factor, GDP (LCU per international \$). https://data.worldbank.org/indicator/PA.NUS. PPP\%0A. [Accessed 10 November 2020].

[76] World Bank. Consumer price index $(2010=100) 2020$. https://data.worldbank.org/indicator/FP.CPI.TOTL. [Accessed 10 November 2020]. 